\title{
LIVESTOCK PRODUCTION IN SERBIA ON ITS WAY TO EUROPEAN UNION ${ }^{1}$
}

\author{
M.M. Petrovic ${ }^{2}$
}

Contents: In this paper, short review of natural and production resources of Serbia is presented as well as strategic directions and goals in livestock production, goals relating to change of structure (producers, ownership and institutions), development of the market and market mechanisms, rural development and protection of the environment. Main strategic goals include forming of sustainable and efficient livestock production which could be competitive on other markets and at the same time contribute to the growth of national income, provide food of animal origin to satisfy the demand of consumers regarding safety and quality of products, protect the environment from the negative effects of the livestock production, prepare livestock producers in Serbia for integration into EU, prepare policy of domestic support and trade of livestock products according to WTO regulations, etc. Chapter relating to harmonization with EU contains short explanation of »Agreement on stabilization and accession« between Serbia and EU, free trade zone, legal standards relating to livestock production, legislation, and development of quality and safety of food.

In chapter on livestock production the present situation was reviewed and potential solutions for current problems through development of mechanisms for integration processes into WTO and EU presented (strategy of development of cattle, pig, sheep and goat and poultry production).

Key words: livestock production, EU, WTO, ISO, HACCP, cattle production, sheep production, pig production, poultry production, standards, quality, food.

\section{Introduction}

The Republic of Serbia disposes with significant natural resources (agricultural land, climate, water plant and animal resources, etc.) and considerable capacities and potentials (population engaged in agriculture, livestock resources, plant and animal selection, production and processing capacities - buildings and equipment, developed expert and scientific activities, etc.). Agricultural producers with small size farms have reduced the number of heads of livestock as well as production volume. With moderate financial means, present knowledge and adequate agricultural policy and incentive these farmers can continue to exist but cannot become important factor of future development. Modern market producers are present but their development is very slow. Negative factors influencing the agriculture are reduced purchasing power and loss of domestic and foreign markets.

Unlimited and free access to the largest market for agricultural products (EU - over 450 million inhabitants), developed system of standards in veterinary medicine, food safety and quality as well as considerable financial means which would be gained by Serbia upon joining and entering the EU from its budget through mutual agricultural and policy of rural development represent basic benefits for livestock production and agriculture of Serbia in regard to processes of its integration into EU. Integration process will cause great changes which shouldn't only be product of euro-integration processes but also results of established economical practice in entire agricultural sector. Integration processes will cause changes in the structure of production, farms, resources management, systems of production control, relation to environment protection and rural development.

Objective of livestock production in Serbia should be increase of general profit and realization of process of integration into EU to mutual benefit. In this regard, strategy of association to EU in the field of agriculture demands serious approach through detailed knowledge of all economical regularities. In countries of EU and USA strategy relating to health status of food stuff products, adopted and applied since 1998, demands obligatory application of the HACCP concept in production, processing, distribution, storing, preparation and use of food products. Application of this concept is obligatory for all food products imported to EU and USA. In Serbia, there is absence of harmonization of regulations relating to production and marketing of products with those in EU, monitoring, certification, registration of slaughterhouses and dairy plants for export. There are no legal regulations concerning mentioned issues adopted or harmonized with legislative regulations of EU.

\footnotetext{
${ }^{1}$ Review paper - Pregledni rad, supported by the Ministry of Science and Environment Protection, Project no. TR6858 - Rad je finansiran od strane Ministarstva za nauku i zaštitu životne sredine Projektom broj: TR6858

${ }^{2}$ Dr Milan M Petrović, scientific counselor, Institute for Animal Husbandry, Belgrade-Zemun, Serbia and Montenegro
} 


\section{Resources}

Very favourable natural and production resources of Serbia (soil characteristics, climate and water resources, great potential in agricultural sector) are not fully utilized. With change of agricultural policy, livestock production can contribute considerably more to the economical development of the country. In regard to the structure of agricultural production in Serbia $60 \%$ originates from plant and $40 \$$ livestock production (EU - 70\% from livestock and 30\% from plant production). Serbia disposes with approx. 0,60 ha of agricultural soil per capita/inhabitant, 0,50 ha of cultivable land per capita/inhabitant which is above the average for European countries. Close to $90 \%$ of land is in private ownership and the rest is owned by the state or firms. There are over 850.00 small size farms predominantly households-farms with up to 3 ha of land $(58,1 \%)$, and only $0,8 \%$ farms has $15-20$ ha, and $0,5 \%$ more than 20 ha of cultivable land in ownership.

\section{Directions}

Basic strategic direction in livestock production of Serbia should follow those determined in agriculture. Strategy of agriculture in Serbia has defined objectives of agricultural policy suggesting main directions of the development necessary in order to accomplish set goals.

Basic directions:

- Change of the structure (producers, ownership and institutions);

- Development of the market and market mechanisms;

- Rural development and protection of the environment.

Basic strategic goals.

- Development of sustainable and efficient livestock production competitive on other markets and which contributes to the national income;

- Provision of food of animal origin which will satisfy the consumer demand in regard to quality and safety;

- To ensure the support for sustainable rural development;

- Protection of the environment from the effects of livestock production;

- Preparation of livestock production in Serbia for integration into EU;

- Preparation of the policy of domestic support and trade in livestock production according to regulations of WTO.

\section{Harmonization with EU (demands)}

"Agreement on stabilization and accession" between Serbia and EU, when concluded will enable creation of free trading zone including Serbia, its neighbouring countries and 25 EU countries. Adopting of set of laws, regulations and procedures according to which the Union is functioning

Legal standards relating to livestock production are abundant. They include everything from standards in livestock breeding, animal health and food safety to identification of domestic animals and products for protection of consumers. Some of the regulations such as EU standards for slaughter houses and dairy plants should be implemented as soon as possible since without them Serbia has no passage to EU market.

Of total budget of EU in amount of 105 billion euros almost half or 46 billion euros represents the agricultural budget. In order for such budget intended for agriculture to be functional there are mechanisms such as Common agricultural policy (CAP). Serbia has no obligation to apply CAP prior to accessing EU but it has to develop set of different implementing mechanisms before becoming member state.

Many countries already integrated or in the procedure of becoming member states received great financial assistance (Hungary received for agriculture 1,5 billion euros for period 2004 to 2006). Especially important element concerning agriculture is system of structural funds of $\boldsymbol{E} \boldsymbol{U}$, financial measures for rural development. Serbia has to develop as soon as possible mechanisms which would enable it to use those funds 
and means as they become accessible. Because of that Serbia needs to make its own support plan for livestock production and agriculture in general.

\section{Legal regulations}

The Republic of Serbia has to harmonize and implement legal regulations relating to animal breeding and veterinary medicine and practice according to same legal regulations in EU countries. Reasons for this are various; firstly, this would influence faster accession and also inclusion of Serbia into international trading. Integrated control in production of food in EU and clear regulations providing this control enable constant monitoring and control for presence of certain diseases of domestic animals, control of different toxic and other harmful substances, etc. Contrary to common agricultural policy of EU, applicable only for EU member states, each country exporting food or agricultural products to EU has to comply fully with existing legislation of EU. Therefore, objective is total harmonization with veterinary and sanitary standards of EU. Because of mentioned reasons it is necessary to adopt strategic and legal documents relating to animal breeding, establish veterinary control and control of food safety as basis of systematic harmonization with EU, establish necessary mechanisms such as Agency for laboratories, registration of households and animal identification system.

\section{Improvement of the quality (standards)}

Providing of quality and safety of food has gained international importance with globalization of the market and it is in the authority of governments, producers but also consumers in developed and less developed and developing countries. According to assessment of WTO (World Trade organization), great changes will occur in the beginning of $21^{\text {st }}$ century in the systems of food production, especially due to introduction of new technologies and increased food trading. Such changes will enable improvement in human nutrition and health, ensure sufficient quantities of biologically valuable food. Trading as well as new technologies will contribute to general development and welfare, but at the same time cause new risks in regard to safety of human nutrition. Main aspects relating to EU strategy in the field of food safety are not free borders and choice but security, risk evaluation and caution. EU legislation includes all aspects of food safety from research and animal nutrition to final product (White Paper on Food Safety). Production of safe food, except to protect own population, enables exit of Serbia as equal partner to world market.

Food safety

Question how to realize adequate and valid protection of consumers in regard to safety and health status of human population and animals is very important. These reasons are strong enough and induce establishing of unique regulations regulating activities in the field of breeding, production and processing of domestic animals, meat and milk, as well as product obtained from them by establishing set of unique rules regulating the trade of live animals and products of animal origin. In conditions of increased liberalization of the market it will be necessary to harmonize legal regulations/legislation in the field of quality and safety of food with international standards in order for domestic products to be equal with similar products on the international market. In order to protect consumers it will be necessary to improve the quality control and monitoring of food safety in production and marketing, to ensure the responsibility in food production by application of the concept of risk evaluation /HACCP/. It is necessary to include all phases after primary production: preparation, processing, packaging, storing, distribution, transport, handling and sale of products.

Sector of food industry places demands on livestock production as raw material base inducing GPP (good production practice), ISO system, HACCP and other solutions in livestock production and agriculture. However, we are still behind other countries in regard to quality demands on the market. Development of quality is related to chain of difficulties of organizational and other nature in livestock production organized on small size farms. Therefore obligation to gradually introduce quality standards and regulations relating to display and marking which would be similar to those present in EU, as well as harmonization with health standards and standards relating to protection of environment determined within EU is important.

Finally, demands for faster harmonization of our agricultural policy with Common Agricultural Policy (CAP) will depend on announced reform action of EU after year 2006 since budget support is determined until this year. Reform will certainly be defined in direction of reducing this support and moving 
the financial means more towards projects of sustainable development, protection of the environment and productions with prefix "organic". So, we are expecting much unknown in this field, except legislation in agriculture.

\section{Livestock production (strategy)}

On of the main objectives of the development of livestock production in Serbia is increase of its share in total value of agricultural production from current $40 \%$ to $60-65 \%$ (which is average in EU, approx. $70 \%)$.

Selection activities in animal breeding. Activities in future period relating to selection and breeding in livestock production should be harmonized with recommendations of international associations for tracing of origin and production performances in domestic animals (ICAR- International Committee for Animal Recording, INTERBULL, EAAP-European Association of Animal Production). However, Serbia is still not member of any of mentioned associations. Based on EU regulations the following should be realized: unique data base containing records for all types of domestic animals, establish unique systems and models for tracing production data and realization of estimation of breeding value by applying unique breeding programmes, form successful organizations and associations of breeders creating assumption/prerequisite for more organized work through these associations on national level and per species of animals, improve work of progeny and performance centres for testing and production of bull, boar, male goat and ram semen.

Also, objective is that $80 \%$ of total population of cows, pigs, sheep and other species of domestic animals in Serbia be included in control of performance traits through analysis of the quality of products (milk, meat, wool, eggs, etc.) in order to determine their commercial value through authorized neutral laboratories and experts, providing equipment for selection services in different regions and districts, adequate equipment for measuring of production traits and forming of experimental centre for education of young experts (agronomists) and livestock producers (education range).

CATTLE PRODUCTION Present level of cattle production with average of bellow two cows per household and production per cow of approx. $3000 \mathrm{~kg}$ of milk, as well as small size of farms are not consistent with developed cattle breeding. In order to achieve objectives such as increase of meat and milk production for domestic market and future accession to EU it is necessary to apply measures of development in cattle breeding.

Production of milk. Increase of milk production and demand in Serbia can be achieved through agricultural policy taking into account key technological, economical and organizational factors of development of this production. Main reasons for increase of domestic milk production are: existing production is insufficient and cannot satisfy the needs of domestic market and consumption, therefore there is no objective basis and potential for export. Demand will increase with the increase of purchasing power of the population (more dairy products, less fresh milk). In order to achieve maximum of production quotas for milk it is necessary to increase the quantity of milk sold by farmers - milk producers (joining of EU). In this regard several scenarios can be expected: change of Common Agricultural Policy in part relating to incentive and support granted to milk producers in a way that incentive in price of milk is decreased/reduced and direct support to primary producers, animal breeders, producers of milk and beef increased; continuing with existing incentive system (until 2007) of national production quotas for milk by direct payments. Existing quotas are based on sale of milk in certain period. Determining future quotas for milk and direct payments will probably be carried out using similar methods (system of quotas can include number of heads of livestock per unit of surface or payment per agricultural production surface).

Other assumptions deriving from objective fact that Serbia is to become member of WTO soon are also significant and relate to reduction of import protection for milk in relation to basic livestock feed. In other words, milk producers will have to find possibilities for cheaper and more competitive nutrition in order to decrease the production cost (for example: higher share of food deriving from pastures and meadows and use of maize silage as well as some by-products in food industry for cow nutrition). In Serbia, it is necessary to increase the number of heads of cattle and dairy cows in order to ensure better supply of milk on domestic market but also for future milk quotas, improve the quality of milk in accordance with EU standards and modernize breeding-selection work in cattle production (methods and production volume, more animals per household and more households/farms). 
Also, it is necessary to improve the market for livestock, market institutions, also to improve the marketing (direct sale, etc.), permanently develop market-information systems, improve credit lines for short term credits (reproduction material) and long term credits (buildings, production facilities, purchasing of land, etc.), support livestock cooperatives, etc. Advantages are in the possibility for easier purchasing of high quality breeding animals, obtaining of credits, entering the system of added value tax and purchasing of inputs and mutual equipment and specific machines, for instance machines for preparation of livestock feeds.

Fattening of cattle. Solving of all problems in fattening of cattle is based on following assumptions: increase of number of cows and possibility for purchasing of offspring for breeding, increase of main herd/population will influence increase of production of milk and meat ensuring domestic demand and consumption and diminishing the need for import of breeding animals and beef. Similar to milk production, the situation will improve with the increase of heads of cattle also in regard to quotas for direct monetary support and also in relation to accession and joining of EU. Focus on sources of livestock feed such as pastures and meadows which are insufficiently exploited is also significant. It is necessary to realize technological progress in regard to exploitation of meadows and pastures and technologies in livestock production based on them, primarily production of calves for fattening in system cow-calf as well as breeding of calves for fattening (with surplus of calves from dairy herds).

PIG PRODUCTION. Problems in pig production in Serbia are more of economical than technological nature. However, technological level and its improvement are very important considering future competitiveness of this production. Depending on the production system limitations in production are huge:

Large intensive producers: problems relating to liquidity and financial means (credits) for current production, missing financial means for investments, lack of flexibility in adjusting to changes on the market, etc.

Intensive pig production on family households: lack of monetary capital for enhancement of production, problems in payments for sold products and purchasing of inputs (piglets for fattening, livestock feed, etc.).

Traditional production (small producers): education and providing of equipment for expertextension services (advisory and selection) and education of pig breeders.

Consequences of Serbia entering WTO in future will be international competition, prices of pigs and pig meat will probably decrease more than cost of inputs. Answer to this situation will be necessity to reduce production costs (first of all cost of food and piglets) which can be achieved through technological improvement, lower variable and fixed costs. In this regard, family farms engaged in intensive production will have the advantage assuming they comply with prerequisites relating to technological improvement and measures of economical and agricultural policy. Production standards relate to increase of sow fertility and increased efficiency in feed conversion. Improvement of production traits and increase of number of pigs under selection programme will also have effect on this as well as popularization of artificial insemination of sows. It is necessary to systematically solve monitoring of pig production starting with production of piglets (sows) to final product intended for consumers.

Important question in this production is possibility of crediting of current production as well as financing investments. One of solutions (example from western countries) is business associating of producers - breeders in cooperatives. Cooperatives as one form of business associating, organized on local level with savings-credit activity (existing cooperatives have no such attributes) could significantly contribute in business (financial), organizational and expert aspect of development in this field. Possibility of crediting should be associated with commercial (regional) banks. This form of organization can improve and contribute to including of producers into system of added value tax, which would also represent economical advantage in their business management.

SHEEP AND GOAT PRODUCTION. Development of sheep and goat production in short term period demands many activities: increase of number of heads of sheep and goats, forming of nucleus herds for specific sheep and goat breeds as way of forming of main population, selection of native and protected sheep and goat breeds in order to preserve genetic resources and national biological heritage. It is necessary to formulate breed standards and DNA analysis (selected heads of livestock), increase the exploitation of unused meadows and pastures. These resources, with additional improvement measures, can ensure good basis for cheaper production of milk and meat. Main limitations in restoring of these resources is process of depopulation of hilly-mountainous regions which cannot be solved without adequate role of the government and necessary legislation; it is necessary to introduce product certification before marketing (meat, milk, 
products, breeding animals); for all family households engaged in agriculture it is necessary to form unique data base containing information on breeders of sheep and goats, number of heads of sheep and goats, which means that regardless of the fact if they are high quality heads from the genetic aspect they should be identified and recorded/registered in this unique data base; carrying out of improvement measures in sheep and goat breeding through associations of breeders of sheep and goats.

POULTRY PRODUCTION. Production of meat. Considering the constant increase of world consumption of poultry products, especially chicken and turkey meat, it is highly probably that consumption of these products will increase also in Serbia. In order to attain/reach the consumption level in USA and EU, poultry production in Serbia should at least double current production by achieving higher quality, assortment and focus on need to produce chicken and turkey products of special nutrition value; alternative or so called „natural" production should also be introduced, partially; assortment of products should be broadened (as well as consumer circle); preserve and expand breeding of domestic poultry breeds; ensure application of regulations on protection of poultry and hygienic safety of meat (introduction of HACCP concept).

Production of eggs. In production of eggs economical values are important therefore investments in increase of this production are necessary. Primarily government measures directed towards better functioning of credit market are necessary in order for farmers to obtain credits under market conditions. Price of eggs will decrease as consequence of reduced customs obligations (upon entering the WTO) more than process of feed since feed components will be more protected and therefore it is necessary to maintain economical efficiency of the production. This production is influenced by the economy of value/size, lower variable but also fixed costs of production. In this regard advantage is on the side of intensive producers - family agricultural households in comparison to huge production systems. In production of eggs also application of regulations on health protection of poultry and hygienic safety of eggs must be ensured (introduction of HACCP concept).

\title{
STOČARSTVO SRBIJE NA PUTU KA EVROPSKOJ UNIJI
}

\author{
M.M. Petrović
}

\section{Rezime}

U radu je prikazan kratak osvrt na prirodne i proizvodne resurse Srbije kao i osnovni strateški pravci i ciljevi u stočarstvu, ciljevi koji se odnose na promenu strukture (proizvođači, vlasništvo i institucije), razvoj tržišta i tržišnih mehanizama, ruralni razvoj i zaštitu životne okoline. Osnovni strateški ciljevi obuhvataju formiranje održive i efikasne stočarske proizvodnje koja može da bude konkurentna na drugim tržištima, koja doprinosi porastu nacionalnog dohotka, obezbeđuje hranu animalnog porekla, zadovoljava potrebe potrošača u pogledu kvaliteta i bezbednosti, i u funkciji je zaštite životne sredine. Takođe, priprema stočarstva Srbije za integraciju u EU i priprema politike domaće podrške i trgovine u stočarstvu prema pravilima Svetske Trgovinske organazacije su u centru pažnje. Poglavlje koje se odnosi na harmonizaciju sa EU sadrži kratko objašnjenje "Sporazuma o stabilizaciji i pridruživanju" između Srbije i EU, zoni slobodne trgovine, zakonskim standardima u stočarstvu, zakonskoj regulativi, razvoju kvaliteta i zdrastvenoj bezbednosti hrane.

U poglavlju o stočarstvu je na revijalan način prikazano postojeće stanje i mogući način rešavanja problema razvijanjem novih mehanizama uz moguće integrativne procese u STO i EU (strategije razvoja govedarstva, svinjarstva, ovčarstva i kozarstva i živinarstva).

\section{Literature}

1. PETROVIĆ M. M.,LAZAREVIĆ R., LAZAREVIĆ LJ., RADOSAVlJEVIĆ D., ALEKSIĆ S., MIŠČEVIĆ B. (1995): Stanje, mogućnosti i način poboljšanja genetske osnove goveda u brdsko planinskom području. Savetovanje"Brdsko planinska područja, stanje, perspektive i razvoj poljoprivrede, zadrugarstva i sela”, Žabljak, 15-16.juni. 
2. PETROVIĆ M. M. (1997): Stanje u stočarstvu SR Jugoslavije (Govedarstvo). Posebna edicija, p.7-16, Beograd.

3. PETROVIĆ M. M. (1998): Program razvoja stočarstva u Republici Srbiji(Program razvoja govedarstva). Posebna edicija,p. 17-23,Beograd.

4. PETROVIĆ M. M., ŽUJOVIĆ M., HOPIĆ S., KOSOVAC OLGA. (2000): Rasni sastav i oplemenjivanje domaćih životinja u Srbiji. Zbornik radova prvog savetovanja" Nauka, praksa i promet u agraru", p.6467, Vrnjačka Banja.

5. PETROVIĆM. M, LAZAREVIĆ R, MIŠČEVIĆ B, ALEKSIĆ S, .STOJIĆ P. (2001): Cattle Production in Serbia at the Beginning of New Millenium $6^{\text {th }}$ International Symposium "Systems of Animal Breeding and Economic of Animal Production at the Beginning of the New Millenium", 2-5 October, Hotel "Jugoslavija", Yugoslavia, Biotechnology in Animal Husbandry 17(5-6), P. 87-95.

6. PETROVIĆ M.M., BOGDANOVIĆ V., PETROVIĆ P.M., RUŽIĆ-MUSLIĆ DRAGANA, OSTOJIĆ DUŠICA (2002): Mogućnosti unapređenja stočarstva brdsko-planinskog područja Srbije, Biotehnologija u stočarstvu, 18 (5-6), p. 1-8.

7. PETROVIĆ M.M, LAZAREVIĆ LJ. (2003): The Present Situation in the Livestock Production in the Republic of Serbia and Measures for its Improvement 7th International Symposium, Modern Trends in Livestock Production, Biotehnology in Animal Husbadry, 19 (5-6), p.13-23.

8. Strategija industrijskog razvoja Srbije do 2010. godine, separat Agroindustrija -stočarstvo. Institut za stočarstvo, Beograd, 2001.

9. Strategija privrednog razvoja Srbije do 2010. godine: Ministarstvo za nauku, tehnologiju i zaštitu životne sredine Republike Srbije,2002.

10. WTO (2003): Republic of Serbia, Agriculture Sector Review - Final Report.

11. Poljoprivreda Srbije ka Evropskim integracijama (2004): Ministarstvo poljoprivrede, šumarstva i vodoprivrede Republike Srbije

12. Strategija poljoprivrede Srbije (2004): Ministarstvo poljoprivrede, šumarstva i vodoprivrede Republike Srbije.

13. Nacionalna strategija Republike Srbije za pristupanje Srbije i Crne Gore Evropskoj uniji.Kancelarija Vlade Republike Srbije za pridruživanje Evropskoj uniji, 2005. 